\title{
The relationship between climate and Rothrock sagebrush colonization patterns
}

\author{
KENNETH M. BAUER, ERIC L. BERLOW, AND CARLA M. D'ANTONIO'
}

Authors are Rangeland Ecologist, Linacre College, Oxford University, St. Cross Road, Oxford OXI 3JA, United Kingdom; Assistant Research Scientist, University of California White Mountain Research Station, 3000 E. Lime St., Bishop Calif, 93514 and Visiting Scholar Department of Integrative Biology,; Professor, Department of Integrative Biology, 3060 VLSB, University of California, Berkeley Calif, 94720; ' current address is USDA-ARS, 920 Valley Road, Reno, Nev. 89512.

\begin{abstract}
In montane meadows of the southern Sierra Nevada mountains (Calif., USA), Rothrock sagebrush (Artemisia rothrockii G.) has expanded into sites once dominated by herbaceous species. We explored the relationship between climate and shrub establishment by estimating Rothrock sagebrush age distributions from growth rings. We compared these age distributions with annual records of spring snowpack and summer precipitation across 4 vegetation types that differed in water table depth, soil moisture, and vegetation cover. In the 2 vegetation types where the water table is consistently deeper than $1 \mathrm{~m}$, Rothrock sagebrush stands were up to $\mathbf{4 0}$ years old and had relatively even age structures that showed no strong relationship to climate. In the 2 vegetation types with a shallow water table - but with contrasting soil moisture and herbaceous cover - the majority of shrubs colonized synchronously between 1984 and 1994, a relatively dry period that followed the wet 1982 to $1983 \mathrm{EI}$ Niño. These and other published data suggest that initial shrub colonization of new sites is facilitated by wet years, which may increase seed production, germination, and seedling survival. However, once sagebrush stands are established and local seed supply is abundant, its continued recruitment seems independent of climate.
\end{abstract}

Key Words: Artemisia rothrockii, shrub invasion, montane meadows, seedling establishment, Sierra Nevada, Golden Trout Wilderness, demography

Grassland ecosystems throughout the world have experienced shrub encroachment across a wide range of environments (West 1983, Archer 1989, 1995, Vavra et al. 1994, Arnalds and Archer 1999, Van Auken 2000, Roques et al. 2001). Like other semi-arid rangelands of the western United States, large montane meadows (up to $\sim 10 \mathrm{~km}$ long) of the southern Sierra Nevada Mountains, Calif. exhibit shrub expansion. In this region, repeat photographs, anecdotal accounts, and pollen data suggest that Rothrock sagebrush (Artemisia rothrockii G.), was historically restricted to the dry meadow fringes, and began invading herbaceous meadows after intensive livestock grazing beginning in the mid 1800's (Ratliff 1985, Odion et al. 1988, Menke et al. 1996, Dull 1999).

Research was funded by an NSF grant (DEB-9815813) to C.M.D. and E.L.B., an NSF Postdoctoral Fellowship to E.L.B., grants from the Jepson Herbarium (Heckard Fund) and the Hellman Family Fund to C.M.D., and a fellowship to K.M.B. from the White Mountain Research Station. The authors thank the IRT internship program (White Mountain Research Station) for assistance in the field.

Manuscript accepted 30 Dec. 2001.

\section{Resumen}

En las praderas montanas del sur de las montañas Sierra Nevada (California, E.U.A) el "Rothrock sagebrush" (Artemisia rothrockii $\mathrm{G}$.) se ha expandido a sitios una vez dominados por especies herbáceas. Exploramos la relación entre el clima y el establecimiento de arbustos mediante la estimación de la distribución de edades del "Rothrock sagebrush" a partir de los anillos de crecimiento. Comparamos estas distribuciones de edad con los registros anuales de acumulación de nieve y precipitación de verano a lo largo de 4 tipos de vegetación que diferían en la profundidad del manto fréatico, humedad del suelo y cobertura vegetal. En los 2 tipos de vegetación en los cuales la profundidad del manto fréatico es consistentemente mayor de $1 \mathrm{~m}$, la población de "Rothrock sagebrush"fue hasta de $\mathbf{4 0}$ años de edad, y tenía un estructura de edades relativamente uniforme que no mostró una fuerte relación con el clima. En los 2 tipos de vegetación con manto fréatico poco profundo, pero con humedad del suelo y cobertura vegetal contrastantes, la mayoría de los arbustos colonizó el área sincrónicamente entre 1984 y 1994, un periodo relativamente seco seguido por un periodo húmedo del Niño, que fue de 1982 a 1983. Estos y otros datos publicados, sugieren que la colonización inicial de arbustos en nuevos sitios es facilitada por los años húmedos, lo cual puede incrementar la producción de semilla, la germinación y la sobreviviencia de las plántulas. Sin embargo, una vez que las poblaciones de "Sagebrush"están establecidas y el suministro local de semilla es abundante, el establecimiento de nuevas plántulas parece ser independiente del clima.

Though cattle continue to graze some meadows in the Sierra Nevada, their numbers are under tighter regulation by the United States Forest Service (USFS), and stocking rates are up to 2 orders of magnitude less today than 100 years ago (Del Hubbs, USFS, personal communication).

Rothrock sagebrush expansion has been attributed to increases in meadow aridity. Grazing and trampling along the stream banks cause channel incision and are associated with the lowering of the water table in adjacent meadows (Platts 1979, Odion et al. 1988, Schoenherr 1995, Knapp and Matthews 1996, Kirchner et al. 1998). Consistent with the notion that sagebrush expansion is a response to increased site aridity, sagebrush is predictably abundant on 'abandoned' meadow terraces in our study sites, along incised stream channels where the water table is deeper than 1 meter (Benedict 1983, Sarr 1995, Berlow et al. in press). However, sagebrush also occurs in moist herbaceous meadows on 
low terraces, where the spring water table is shallow $(0.2$ to $0.6 \mathrm{~m})$. A lower water table and increased site aridity do not fully explain all the patterns of sagebrush distribution (Berlow et al. in press).

Changes in fire regimes have also been proposed to explain shrub expansion in grassland ecosystems (Milchunas and Lauenroth 1993, Vavra et al. 1994, Van Auken and Bush 1997). However, there is strong evidence that fires in this region were not frequent enough to be an important source of mortality for sagebrush in these montane meadows (Wood 1975, Dull 1999). Others suggest that effects of livestock and stream incision are confounded by significant regional warming in the Sierra Nevada since the end of the 'little ice age' (about 1900), which may have facilitated shrub expansion independent of grazing (Scuderi 1993, Millar and Woolfenden 1999).

Here, our objective is to examine the relationship between climate and Rothrock sagebrush establishment by comparing the age distributions of shrubs to annual variation in precipitation, over the past $\sim 40$ years. By comparing the relationship between annual climate and shrub recruitment across 4 contrasting microhabitats we were able to address the following questions:

1) Did Rothrock sagebrush colonize different microhabitats synchronously in response to annual variation in regional climate?
2) Are Rothrock sagebrush establishment events associated with drier (or wetter) than average years, and does this relationship vary spatially among different habitat types?

\section{Materials and Methods}

\section{Site Selection}

This study was conducted in the Golden Trout Wilderness, located on the Kern Plateau of the southern Sierra Nevada Mountains, Calif., USA $\left(36^{\circ} \mathrm{N}, 118^{\circ} \mathrm{W}\right)$. In a series of open basins along the South Fork Kern River and its tributaries, the largest meadows of the entire range (up to $30 \mathrm{~km}^{2}$ ) are found at elevations between $2,500 \mathrm{~m}$ to $3,000 \mathrm{~m}$. Despite a history of grazing in this area since the late 1800's, the meadow vegetation is almost entirely native. The only common exotic, dandelions (Taraxicum officinale G.H. Weber ex Wiggers), comprises less than $0.1 \%$ cover in all the vegetation types included in this study (Berlow et al. in press).

These meadows are moist but occur within a semiarid landscape where annual precipitation is about $500 \mathrm{~mm}$ (Albert 1982, Odion et al. 1988). They are snowcovered in the winter and snowmelt is the most important source of water for the meadow vegetation. Fluvial processes, including stream channel incision, have created distinct meadow terraces where water table depth increases with vertical distance from the active stream channel. Channel incision has left 'abandoned' meadow terraces that are sometimes more than 2 meters above the level of the stream (Bryant and Nelson 2000).

\section{Data Collection}

We collected Rothrock sagebrush stems from Mulkey and Ramshaw meadows (2,806 and 2,597 m elevation, respectively) during 1997 and 1998. Each meadow is about 8 to $10 \mathrm{~km}$ long. Rothrock sagebrush occurs in extensive stands on high terraces where the water table is consistently deeper than $1 \mathrm{~m}$. The shrub is patchily distributed on lower terraces, where the early summer water table is 0.2 to $0.6 \mathrm{~m}$ deep (Berlow et al. in press). Within these 2 distinct water table regimes, Rothrock sagebrush may be found with an herbaceous understory and fine-textured soil, or with bare, coarse-textured soil and a sparse understory in the inter-shrub spaces (Table 1). We sampled shrubs in 4 vegetation types, hereafter referred to as 'low-terrace Sage-Herb' (low terrace sagebrush with an herbaceous understory), 'low-terrace Sage' (low terrace sagebrush with abundant exposed soil), and 'high-terrace Sage-Herb' (high terrace sagebrush, herbaceous understory), and 'high-terrace Sage' (high terrace sagebrush, exposed soil). Low-terrace Sage, low-terrace Sage-Herb, and high-terrace Sage sites were located in Mulkey Meadow; high-terrace Sage-Herb areas

Table 1. Biotic and abiotic characteristics of the Rothrock sagebrush vegetation types sampled for shrub age distributions (1998-2000).

\begin{tabular}{|c|c|c|c|c|c|c|}
\hline Vegetation & Meadow & $\begin{array}{c}\text { Water Table } \\
\text { Depth }\end{array}$ & Soil Type $^{1}$ & $\begin{array}{c}\text { Soil Water } \\
\text { Content }\end{array}$ & $\begin{array}{c}\text { Total Herb } \\
\text { Cover }\end{array}$ & 5 Most Common Herbs ${ }^{3}$ \\
\hline & & $(\mathrm{m})$ & & $\left(\mathrm{m}^{3} \mathrm{~m}^{-3}\right)^{2}$ & $(\%)$ & \\
\hline $\begin{array}{l}\text { High-Terrace } \\
\text { Sage-Herb }\end{array}$ & Ramshaw & $>1$ & $\begin{array}{l}\text { Mollisols (Cumulic } \\
\text { Haplocryolls) }\end{array}$ & $6-18$ & $35-40$ & $\begin{array}{l}\text { Carex spp. } \\
\text { Koeleria macrantha L. Schultes } \\
\text { Muhlenbergia richardsoni } \\
\text { Potentilla spp. } \\
\text { Poa Secunda ssp. juncifolia }\end{array}$ \\
\hline & & & Mollilsols & & & Eriogonum umbellatum \\
\hline $\begin{array}{l}\text { High-Terrace } \\
\text { Sage }\end{array}$ & Mulkey & $>1$ & $\begin{array}{l}\text { (Cumulic and } \\
\text { Pachic } \\
\text { Haplocryolls) }\end{array}$ & $4-9$ & $15-20$ & $\begin{array}{l}\text { Juncus balticus } \\
\text { Lupinus spp. } \\
\text { Muhlenbergia richardsonis } \\
\text { Poa secunda ssp. juncifolia }\end{array}$ \\
\hline $\begin{array}{l}\text { Low-Terrace } \\
\text { Sage-Herb }\end{array}$ & Mulkey & $0.2-0.6$ & $\begin{array}{l}\text { Mollisols } \\
\text { (Aquic } \\
\text { Haplocryolls } \\
\text { and Typic } \\
\text { Cryoaqualls) }\end{array}$ & $15-30$ & $70-80$ & $\begin{array}{l}\text { Poa secunda ssp. juncifolia } \\
\text { Muhlengergia richardsonis } \\
\text { Carex spp. } \\
\text { Eleocharis spp. } \\
\text { Erigeron Peregrinus }\end{array}$ \\
\hline $\begin{array}{l}\text { Low-Terrace } \\
\text { Sage }\end{array}$ & Mulkey & $0.2-0.6$ & $\begin{array}{l}\text { Entisols } \\
\text { (Oxyaquatic } \\
\text { Cryofluvents) }\end{array}$ & $4-9$ & $20-25$ & $\begin{array}{l}\text { Eriogonum umbellatum } \\
\text { Muhlengergia richardsonis } \\
\text { Ivesia capestris } \\
\text { Poa secunda ssp. juncifolia } \\
\text { Antennaria } \text { spp. }\end{array}$ \\
\hline
\end{tabular}

${ }^{1}$ From Bryant and Nelson (2000).

${ }^{2} 0$ to $30 \mathrm{~cm}$ depth measured in mid-summer using Time Domain Reflectometry (TDR) probes.

${ }^{3}$ Listed in order of abundance, based on \% canopy cover estimated using 0.5 x $0.5 \mathrm{~m}$ point-intercept quadrats during peak flowering. (Berlow et al., unpublished data). 
were in Ramshaw meadow. The study area of Ramshaw meadow has been closed to exclude livestock grazing since 1983 (Knapp et al. 1998).

We sampled from each vegetation type at $5,50 \mathrm{~m}^{2}$ sites separated by at least $50 \mathrm{~m}$. For each site we selected 25 individuals at random points along a $10 \mathrm{~m}$ transect. Since accurate age determination requires that the stem be woody, we did not sample young seedlings (less than $\sim 2$ yrs. old) that had not developed a woody stem. In each plot, we also selectively collected at least 1 of the largest individuals to estimate the age of the oldest plants. A total of 502 individuals were sampled. Each plant was excavated from the soil with hand tools and cut at the stem, as close to the roots as possible.

In the laboratory, we followed the techniques suggested by Ferguson (1964) to count growth rings of sagebrush stems. Each stem was cut at its widest point, sanded, and moistened with water to enhance contrasts between the early wood and late wood cells within each ring. Using a dissecting lamp, we counted growth rings of each stem twice along the most visible radius. To acquire data about growth rates, we measured the radius of each stem, using the same axis of rings from which we had determined its age. The centers of sagebrush stems disintegrate as plants age, complicating the counting of growth rings. However, this prevented us from counting rings in less than $1 \%$ of the stems we sampled, and primarily in individuals 20 years and older.

In Mulkey and Ramshaw meadows, we also surveyed the entire sagebrush population in each sampling site to estimate its size structure. We divided the population into 4 groups based on appearance and size: small $(<10 \mathrm{~cm})$, medium (10 to 20 $\mathrm{cm})$, large $(>20 \mathrm{~cm})$, and dead. This census allowed us to assess whether there was systematic variation among vegetation types in the proportion of very young $(<2$ yrs) and dead individuals, which were necessarily excluded from the ring counting.

We examined annual variation in spring snowpack and summer rains using data gathered by the California Department of Water Resources (CDWR) for over 40 years. The CDWR has recorded the water content of snowpack $(\mathrm{cm})$ at Ramshaw meadow monthly since 1958 (except from 1959 to 1968 , and from 1971 to 1972 ). Peak snowmelt in these meadows occurs between April and early June, with large variations from year to year. We used May snowpack, the last month for which data are reported each year by CDWR, as an indicator of spring and summer water availability. Mulkey Meadow is approximately $200 \mathrm{~m}$ higher in elevation than Ramshaw, and is likely to have a later snowmelt date (E. Berlow, personal observation). However, field observations also suggest that Mulkey and Ramshaw show similar annual trends in relative water availability. Thus, this snowpack data are a good relative indicator of annual variation in water availability for the region, rather than an absolute measure of water availability in a given year. For each year that data were available, the May snow water content was standardized relative to the mean of this period (1958 to 1997). In addition to the CDWR data, daily precipitation has been recorded at the USFS weather station in Cottonwood Basin (adjacent to Mulkey and Ramshaw meadows) since 1987. For each year between 1987 and 1997, we calculated the total
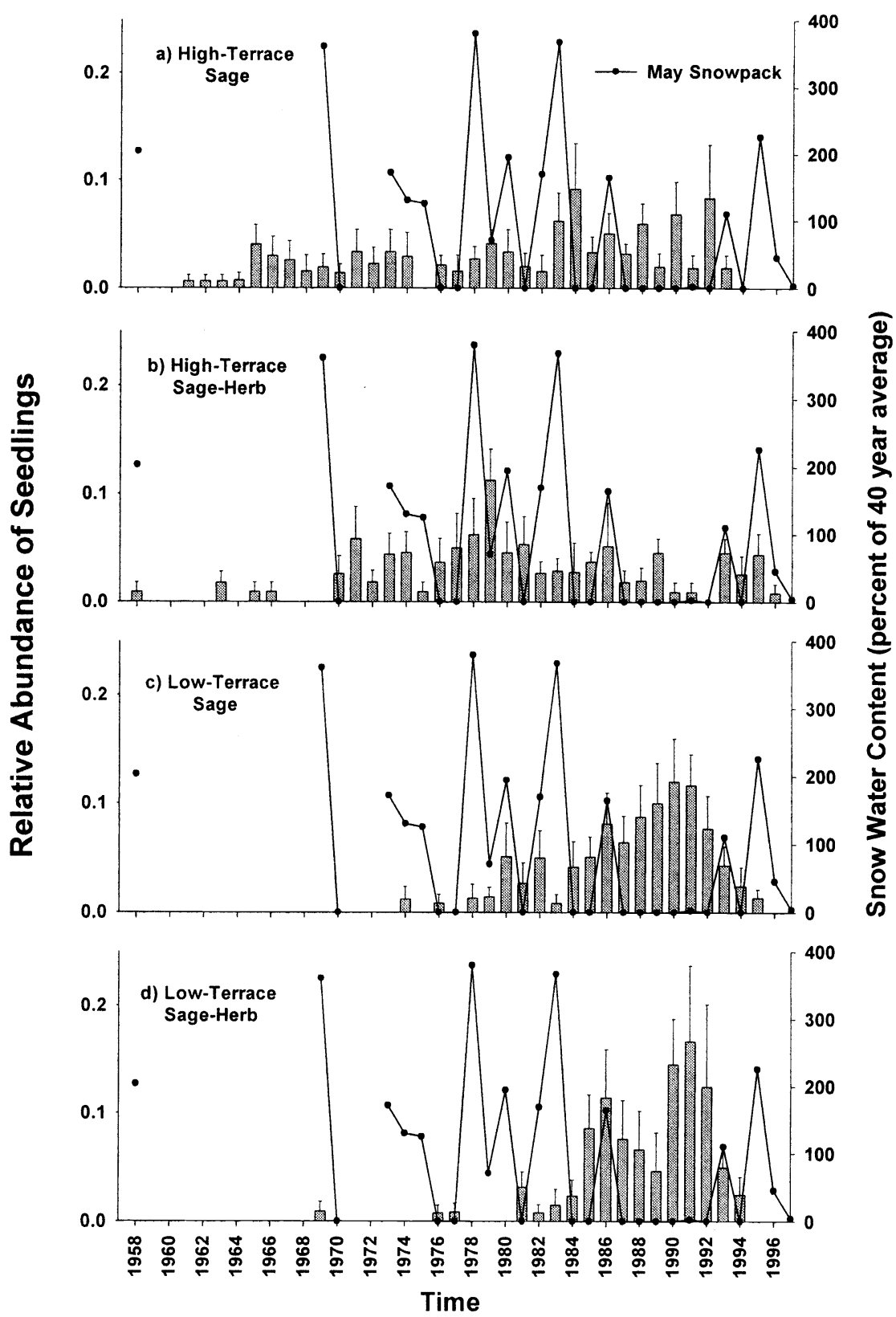

Fig. 1. Relationship between annual recruitment of Rothrock sagebrush seedlings (estimated by counting growth rings) and water content of May snowpack for 4 habitat types. Bar data are relative seedling abundance (the mean + s.e. of 5 sampling sites). The line represents the May snowpack water content $(\mathrm{cm})$ expressed as a percent of the mean snowpack recorded between 1958-1997. 


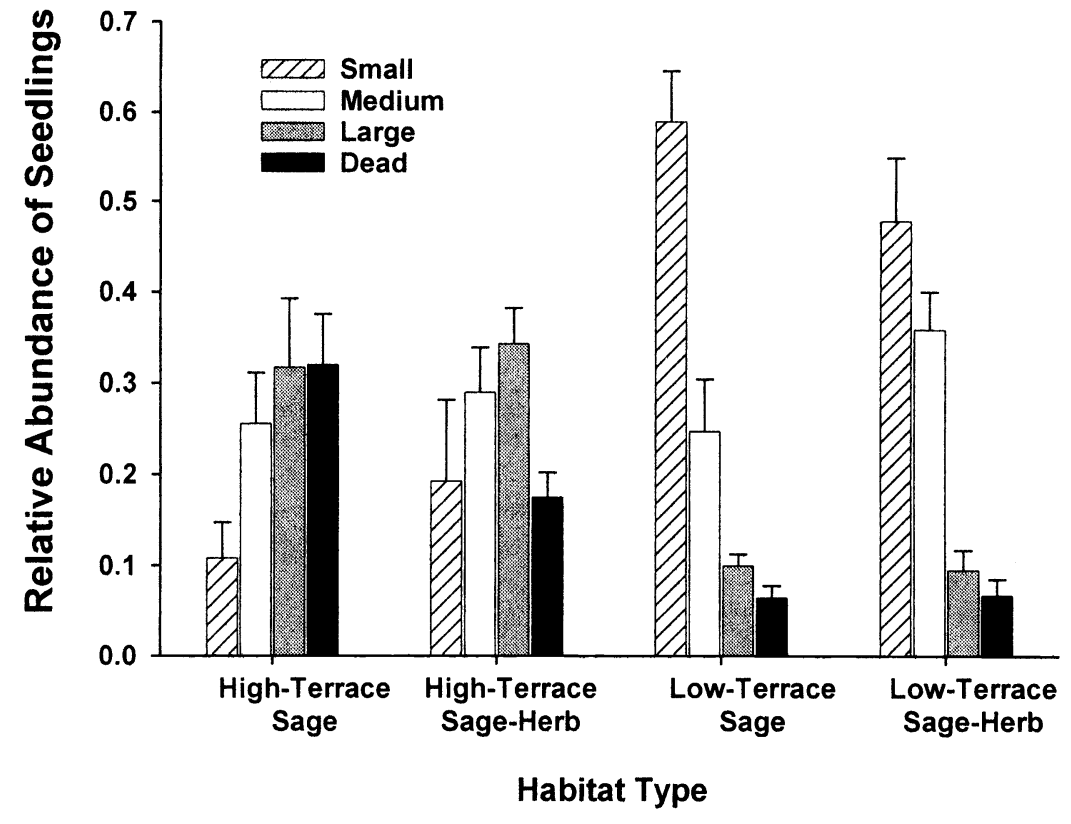

Fig. 2. Size structure of Rothrock sagebrush in 4 vegetation types. Data are the mean ( \pm s.e.) of 5 sampling sites. Size classes are based on the maximum of either height or canopy diameter (whichever was greatest): 'small' $(<10 \mathrm{~cm})$, 'medium' $(10-20 \mathrm{~cm})$, and 'large' $(>20 \mathrm{~cm})$. days of rain and total amount of precipitation over the growing season (1 June to 31 August).

\section{Data Analysis}

We used the Pearson Chi-Square to test whether the frequency distribution of shrub ages differed among the 4 vegetation types. Establishment date was the categorical predictor variable and the total counts of individuals established that year served as the response variable. The age distributions differed significantly among all 4 vegetation types $(\mathrm{p}<0.0001)$. Therefore, we used separate analyses to test for overall differences between the 2 terrace types ('high-terrace' vs. 'low-terrace'), and to test for differences between 2 vegetation types ('Sage' vs. 'SageHerb') within terraces.

We used a 2-way factorial Analysis of Variance (ANOVA) to test for differences among vegetation types in the proportion individuals in each size class ('small', 'medium', and 'large'). The factors for this analysis were 'Terrace' (high vs. low) and 'Vegetation Type' ('Sage' vs. 'Sageeach category of plants. Since data were proportions, all data were arcsine square root transformed prior to analysis, which greatly improved variance homogeneity and normality. of dead individuals, and proportions of Herb'). Separate ANOVA's were used for
We calculated shrub growth rates as the slope of the relationship between age (years) and stem radius ( $\mathrm{mm}$ ). To test for differences in shrub growth rates across 4 vegetation types, we used an Analysis of Covariance (ANCOVA), with stem radius as the response variable, 'Habitat Type' as the categorical predictor variable, and 'Age' as the covariate. Since the interaction of 'Habitat Type' $x$ 'Age' was significant ( $p=0.001)$, we used F-protected pairwise comparisons to evaluate differences among habitat types (SAS Institute Inc. 1988).

\section{Results}

In both low-terrace vegetation types, less than $50 \%$ of the individuals sampled were over 10 yrs. old (Fig. 1). The age distributions of these 2 low-terrace vegetation types were not significantly different, though there was a trend towards a greater number of older individuals in the low-terrace Sage $(p=0.13)$. Most of the low-terrace individuals we sampled colonized between 1984 and 1994 - a relatively dry period that followed the wet 1982 to 1983 El Niño (74 and $85 \%$ for low-terrace Sage and low-terrace Sage-Herb, respectively). So, Rothrock sagebrush appears to have only recently colonized the low meadow terraces that we sampled.

The age distributions of the 2 high-terrace vegetation types were significantly different than the low-terrace types $(\mathrm{p}<$ $0.0001)$. Compared to the low-terraces, individuals of sagebrush in both high-terrace vegetation types were older and recruited steadily over time (Fig. 1). Recruitment in these terraces appeared independent of annual variations in snowpack. Within high-terraces, the age distributions of sagebrush in the Sage and SageHerb vegetation types were significantly different $(p=0.005)$. This difference seems due to: a) early recruitment in the high-terrace Sage in the mid-1960s, b) greater recruitment in high-terrace Sage during the dry period between 1984 and 1992 , c) greater recruitment in high-terrace Sage-Herb between 1977 and 1979 (which included the deepest May snowpack on record), and d) greater recruitment in the high-terrace Sage-Herb following the wet winter of 1995 (Fig. 1).

In our general survey of shrub size classes, the relative abundances of small, medium, and large individuals were similar between the low-terrace vegetation types $(\mathrm{p}>0.15)$, a pattern consistent with age distribution data (Fig. 1). Small sagebrush seedlings $(<10 \mathrm{~cm})$ were significantly more abundant $(\mathrm{p}<0.001)$ in both low-terrace vegetation types than in highterrace ones (Fig. 2). Large $(>20 \mathrm{~cm})$ and dead shrubs were significantly more abun-
Table 2. Rothrock sagebrush stem growth rates in 4 vegetation types.

\begin{tabular}{llccc}
\hline \hline $\begin{array}{l}\text { Vegetation } \\
\text { Type }\end{array}$ & Growth Rate & $\mathrm{R}^{2}$ & $\mathrm{p}$ & $\begin{array}{c}\text { Maximum } \\
\text { Age/Radius }\end{array}$ \\
\hline $\begin{array}{c}\text { High-Terrace } \\
\text { Sage-Herb }\end{array}$ & $\begin{array}{l}\left(\mathrm{mm} \cdot \mathrm{yr}^{-1}\right) \\
(0.059 \mathrm{~b}\end{array}$ & 0.83 & 0.001 & $\begin{array}{c}\left(\mathrm{yr} \cdot \mathrm{mm}^{-1}\right) \\
40 / 2.8\end{array}$ \\
$\begin{array}{c}\text { High-Terrace } \\
\text { Sage }\end{array}$ & $0.046 \mathrm{c}$ & 0.85 & 0.001 & $34 / 1.9$ \\
$\begin{array}{c}\text { Low-Terrace } \\
\text { Sage-Herb }\end{array}$ & $0.069 \mathrm{a}$ & 0.89 & 0.001 & $29 / 1.8$ \\
$\begin{array}{c}\text { Low-Terrace } \\
\text { Sage }\end{array}$ & $0.062 \mathrm{~b}$ & 0.83 & 0.001 & $27 / 2.4$ \\
\hline
\end{tabular}

${ }^{\mathrm{T}}$ Estimated from the slope of the linear regression of stem radius $(\mathrm{mm})$ and shrub age (years).

Habitat types with different letters have significantly different slopes ( $p<0.05$ for F-protected pairwise contrasts). 
dant in the high-terrace vegetation types ( $\mathrm{p}$ $<0.001$ ). Rothrock sagebrush stem growth rates differed significantly among the 4 vegetation types (Table 2). Compared with high terraces, stem growth was $25 \%$ faster in low-terraces. Within each terrace type, growth rates were higher where an herbaceous understory was present, particularly in the high terrace sites.

There were less than 6 total days of rain, on average, during the summer growing seasons between 1987 and 1997. Most of this precipitation comes in the form of brief thundershowers. The mean total summer precipitation during this period was less than $1 \mathrm{~mm}$. Total summer precipitation never exceeded $3 \mathrm{~mm}$, suggesting that it is unlikely to be an important source of water in this system. Our analyses showed no clear relationship between Rothrock sagebrush recruitment and summer precipitation in any of the vegetation types.

\section{Discussion}

We did not observe a consistent or region-wide response of Rothrock sagebrush establishment to climatic variation. However, spatial variation in shrub colonization patterns suggests some conditions under which recruitment is sensitive to annual climatic variation. The almost synchronous colonization by Rothrock sagebrush of 2 distinct low-terrace vegetation types from 1984 to 1994 suggests that patch establishment was driven by external climatic factors. One might hypothesize that low-terrace Sage and Sage-Herb types represent different stages in the aridification of formerly moist, herb-dominated sites (e.g., Schlesinger et al. 1990, Vavra et al. 1994). Or these vegetation types might represent different stages in the colonization of gravel bars deposited by the stream. However, our data show that Rothrock sagebrush independently colonized these sites with a priori differences in surface soil conditions. In comparison, Rothrock sagebrush on high meadow terraces were older. Recruitment over the past 20 years in these areas was more steady and appeared to be less related to climate than recruitment in the lowterrace sites (Fig. 1). Together, these patterns suggest that the initial invasion of sagebrush may be related to climate, but once a stand is established, its continued recruitment is independent of climate.

It is unclear from these data alone if the recent colonization of low terrace sites occurred in response to the wet 1982-83
El Niño or to a subsequent string of dry years (1984 to 1994). While shrub expansion in montane meadows is commonly attributed to an increase in meadow aridity (e.g., Schoenherr 1995), other evidence suggests that it may have been the wet conditions that facilitated colonization of new sites. Studies of shrub expansion in other systems have shown that shrub colonization is sometimes associated with periods of increased water availability, even though these species may ultimately be associated with aridification of these habitats (Brown and Archer 1987, 1999, O'Connor 1995, Brown et al. 1997). In a germination experiment conducted in Mulkey meadow (Berlow et al., in press), Rothrock sagebrush had extremely low germination in xeric microhabitats (mean germination percentage was $<0.05 \%$ ), as well as slow growth and low survival rates. The highest observed rates of germination and seedling growth were in moist meadow microhabitats (Berlow et al., in press). While wet years may also suppress colonization by increasing competition from established herbaceous vegetation (e.g., Harrington 1991), seedling emergence, growth, and survival were consistently high in disturbed micro-sites, which are frequently created by burrowing mammals (Berlow et al., in press). Naturally occurring seedlings in moist meadow areas are almost always associated with gopher mounds (Berlow et al., in press).

Whether shrubs are able to colonize these disturbances in moist areas may depend critically on seed supply. While individual plants can produce over 5,000 seeds, maximum observed germination rates in the field were $<1 \%$ (Berlow et al. in press). Studies of other Artemisia species suggest that most seeds fall within one meter of the shrub (Friedman and Orshan 1975, Wambolt et al. 1989). In our study system, sagebrush seedling density decreased significantly beyond $0.5 \mathrm{~m}$ from reproductive shrubs (Berlow et al., in press). Sagebrush seed dispersal is likely limited due to reduced seed pappus and low seed release height (authors' observations). Thus, wet conditions could be important in increasing Rothrock sagebrush seed production and germination rates, which are critical for colonizing new sites given limited dispersal ability of this species. Invasion rates have been shown to increase rapidly following rare long distance establishment events (Nathan and Muller-Landau, 2000). Thus, once the initial colonists have reached reproductive maturity (after approximately 5 to 7 years), further colonization may accelerate rapidly, independent of climatic variation, due to abundant local seed supply.

The age distributions and climate data presented here are consistent with the idea that moist conditions and local seed supply are critical for shrub recruitment. The first shrubs colonized both low-terrace Sage and low-terrace Sage-Herb during or immediately following wetter than average years (e.g., 1973 to 1974 for the former, 1969 for the latter) (Fig. 1c, 1d). Similarly, distinct increases in establishment rates occurred in both areas immediately after the wet 1982 to 1983 El Niño. Furthermore, the time lags between colonization pulses were approximately 6 to 8 years - the time it takes for seedlings to reach reproductive maturity (Fig. 1c, 1d). By 1984, local seed supply may have been sufficient to promote rapid recruitment independent of climate.

There is also some evidence that, in the older high-terrace sage-herb stands, Rothrock sagebrush establishment increased during wet years. For example, 2 distinct increases in recruitment within high-terrace Sage-Herb stands (1970 and 1978) were preceded by years with a spring snowpack $300 \%$ of the average (Fig.1). However, there are insufficient climate data to rigorously evaluate the trends of establishment before 1974. After that time, recruitment in high terraces appears continuous and independent of climate. Since the high terrace stands are older and more expansive than low terrace patches, seed supply may not be limiting. Recruitment opportunities may instead depend on the death of adult individuals.

Our growth ring data suggest that the maximum shrub age was 40 years. We assessed whether the age distributions derived from our growth ring data were biased by being based entirely on living individuals. It is possible that individuals died earlier, decomposed, and were not sampled. In aerial photographs taken of Mulkey meadow in 1955 and 1974, Rothrock sagebrush were present in the high-terrace sites but not in the low-terrace sites. These patterns suggest that our age distribution data accurately represent the recent establishment of sagebrush in the low-terrace sites. The aerial photographs, the relative abundance patterns of dead individuals, as well as the size class distributions, suggest that, if anything, we under-estimated the age of the high-terrace Sage stands and under-estimated the abundance of recent recruits in the low-terrace patches (Fig. 2).

Our results are consistent with other studies that suggest it is the interaction of 
local factors and broader site or climatic conditions that ultimately determine the timing and patterns of shrub encroachment (e.g., Williams and Hobbs 1989, Harrington 1991, Gosz 1993, O’Connor 1995, Miller and Halpern 1998). Our data show that Rothrock sagebrush recently and rapidly colonized meadow areas where the water table is shallow. These and other data suggest that initial colonization of new areas may be facilitated by moist conditions, given a nearby seed source and exposed soil (Berlow et al, in press). In areas where sagebrush cover is already well established, sagebrush will likely continue to recruit independent of climate and grazing regime. Understanding this spatial and temporal variability in the mechanisms of shrub colonization may help land managers identify critical times or places where they might intervene to manage shrub expansion.

\section{Literature Cited}

Albert, C.P. 1982. A survey of factors influencing the condition of the stream zone in the Golden Trout Wilderness. MSc Thesis, Sonoma State Univ., Rohnert Park, Calif.

Archer, S. 1989. Have southern Texas savannas been converted to woodlands in recent history? Amer. Natur. 134:545-561.

Archer, S. 1995. Tree-grass dynamics in a Prosopis-thornscrub savanna parkland: Reconstructing the past and predicting the future. Ecosci. 2:83-89.

Arnalds, O. and S. Archer. 1999. Case Studies of Rangeland Desertification: Proceedings from and International Workshop in Iceland. Agr. Res. Inst., Reykjavík, Iceland.

Benedict, N.B. 1983. Plant associations of subalpine meadows, Sequoia Nat. Park, California. Arctic Alpine Res. 15:383-396.

Berlow, E.L.,C.M. D'Antonio, and S.A. Reynolds. 2002. Shrub expansion in montane meadows: The interaction of local-scale disturbance and site aridity. Ecol. Appl. 12:1103-1118

Brown, J.H., T.J. Valone, and C.G. Curtin. 1997. Reorganization of an arid ecosystem in response to recent climate change. Proc. Nat. Acad. Sci. 94:9729-9733.

Brown, J.R. and S. Archer. 1987. Woody plant seed dispersal and gap formation in North American subtropical savanna woodland: The role of domestic herbivores. Vegetatio 73:73-80.

Brown, J.R. and S. Archer. 1999. Shrub invasion of grassland: recruitment is continuous and not regulated by herbaceous biomass or density. Ecol. 80:2385-2396.

Bryant, L. and K. Nelson. 2000. Upper Kern Plateau meadow system ecological unit inventory, Golden Trout Wilderness and South Sierra Wilderness. Inyo Nat. Forest. Rep. Bishop, Calif.
Dull, R.A. 1999. Palynological evidence for 19 th century grazing-induced vegetation change in the southern Sierra Nevada, California. J. Biogeography 26:899-912.

Ferguson, C.W. 1964. Annual rings of big sagebrush, Artemisia tridentata. Univ. Ariz. Press Papers of Lab. of Tree-ring Res. No. 1. 95pp.

Friedman, J. and G. Orshan. 1975. The distribution, emergence and survival of seedlings of Artemisia herba-alba Asso in the Negev desert of Israel in relation to distance from the adult plants. J. Ecol. 63:627-632.

Gosz, J.R. 1993. Ecotone hierarchies. Ecol. Appl.. 3:369-376.

Harrington, G.N. 1991. Effect of soil moisture on shrub seedling survival in a semi-arid grassland. Ecol. 72:1138-1149.

Kirchner, J.W., L. Micheli, and J.D. Farrington. 1998. Effects of herbaceous riparian vegetation on streambank stability. Tech. Completion Rep., Proj. \#W-872, Univ. Calif. Water Res. Center.

Knapp, R.A. and K.R. Matthews. 1996. Livestock grazing, Golden Trout, and streams in the Golden Trout Wilderness, California: impacts and management implications. North American J. Fisheries Manage. 16:805-820.

Knapp, R.A.,V.T. Vredenburg, and K.R. Matthews. 1998. Effects of stream channel morphology on Golden Trout spawning habitat and recruitment. Ecol. Appl. 8:1104-1117.

Menke, J.W., C. Davis, and P. Beesley . 1996. Rangeland Assessment, p.901-972. In: Menke, J.W., C. Davis, and P. Beesley (eds.), Sierra Nevada Ecosystem Project. Volume III., Sierra Nevada Ecosystem Project. Univ. of Calif., Centers for Water and Wildland Resources, Davis, Calif.

Milchunas, D.G. and W.K. Lauenroth. 1993. Quantitative effects of grazing on vegetation and soils over a global range of environments. Ecol. Monogr. 63:327-366.

Millar, C.I. and W.B. Woolfenden. 1999. The role of climate change in interpreting historical variability. Ecol. Appl. 9:1207-1216.

Miller, E.A. and C.B. Halpern. 1998. Effects of environment and grazing disturbance on tree establishment in meadows of the central Cascade Range, Oregon, USA. J. Vegetation Sci. 9:265-282.

Nathan, R. and H.C. Muller-Landau. 2000. Spatial patterns of seed dispersal, their determinants and consequences for recruitment. Trends Ecol. and Evol. 15:278-285.

O'Connor, T.G. 1995. Acacia karroo invasion of grassland: Environmental and biotic effects influencing seedling emergence and establishment. Oecologia 103:214-223.

Odion, D.C., T.L. Dudley, and C.M. D'Antonio. 1988. Cattle grazing in southeastern Sierran meadows: Ecosystem change and prospects for recovery. p.277-292. In: C.A. Hall and V. Doyle-Jones (eds.), Plant Biology of Eastern California, Mary DeDecker Symposium. White Mountain Res. Sta., Los Angeles, Calif.
Platts, W.S. 1979. Livestock grazing and riparian/stream ecosystems - An overview. p.39-45. In: O.B. Cope (ed.), Forum Grazing and Riparian/Stream Ecosystems. Trout Unlimited, Denver, Colo.

Ratliff, R.D. 1985. Meadows in the Sierra Nevada of California: State of knowledge. USFS Pac. SW For. and Range Exp. Station, Gen. Tech. Rep. PSW-84.

Roques, K., T.G. O'Connor, and A.R. Watkinson. 2001. Dynamics of shrub encroachment in an African savanna: Relative influence of fire, herbivory, rainfall, and density dependence. J. Appl. Ecol. 38:268-280.

Sarr, D.A. 1995. Grazing, graminoids, and hysteresis: Investigating relationships between livestock production, riparian communities, and ecosystem recovery in the southern Sierra Nevada, California. MSc Thesis, Univ. of California, Santa Barbara, Calif.

SAS Institute, Inc. 1988. SAS/STAT user's guide. SAS Institute Inc., Cary, N.C.

Schlesinger, W.G., J.F. Reynolds, G.L. Cunningham, L.F. Huenneke, W.W. Jarrell, R.A. Virginia, and W.G. Whitford. 1990. Biological feedbacks in global desertification. Sci. 247:1043-1048.

Schoenherr, A.A. 1995. A Natural History of California. University of California Press, Berkeley, Calif.

Scuderi, L.A. 1993. A 2000-year tree ring record of annual temperatures in the Sierra Nevada mountains. Sci. 259:1433-1436.

Van Auken, O.W. 2000. Shrub invasions of North American semiarid grasslands. Annual Rev. of Ecol. Systematics 31:197-215.

Van Auken, O.W. and J.K. Bush. 1997. Growth of Prosopis glanulosa in response to changes in aboveground and belowground interference. Ecol. 78:1222-1229.

Vavra, M., W.A. Laycock and R.D. Pieper. 1994. Ecological implications of livestock herbivory in the West. Soc. for Range Manage., Denver, Colo.

Wambolt, C.L., T.P. Walton, and R.S. White. 1989. Seed dispersal characteristics of plains silver sagebrush. Prairie Natur. 21:113-118.

West, N.E. 1983. Ecosystems of the World 5: Temperate deserts and semi-deserts. Elsevier Scientific Publishing Co., Amsterdam.

Williams, K. and R.J. Hobbs. 1989. Control of shrub establishment by springtime soil water availability in an annual grassland. Oecologia 81:62-66.

Wood, S.H. 1975. Holocene stratigraphy and chronology of mountain meadows, Sierra Nevada, California. Earth Resources Monogr. 4:1-180. 